an example, the pedigree of a family in group 1 is shown in Fig. 1.

In group 2 the affected men had no affected sons and no healthy daughters, while the affected women had both healthy and affected sons and daughters. An X-chromosomal inheritance was therefore possible. The pedigree of a family in group 2 is shown in Fig. 2.

\section{Discussion}

An antiserum has been raised against an apparently homogeneous plasma protein fraction containing AHF activity. The majority of patients with von Willebrand's disease had a decreased amount of this protein in their plasma. All the 33 patients with haemophilia A had normal amounts of the AHF-related protein, which is in accordance with the findings in the 22 patients of Zimmerman et al. (1971). It is conceivably the von Willebrand factor that is detected by the antiserum. AHF may reside in, or be complexed with, the von Willebrand factor and be functionally active only in this form. Bouma et al. (1971) also suggested that both activities are located on the same molecule. The exclusion of AHF activity from a Sepharose column shows that it is linked to a high-molecular-weight compound, probably an aggregate of smaller units. Ratnoff et al. (1969) estimated the molecular weight of their AHF to be at least 2,000,000.

In haemophilia A the X-chromosomally induced part of the complex may be missing or malformed, but the von Willebrand factor will still be immunologically detectable. In most patients with von Willebrand's disease an autosomal gene mutation (regulatory gene?) results in a suppression of the von Willebrand factor and consequently also of the complex and of AHF activity in the plasma.

The second type of von Willebrand's disease was apparently a separate entity. The clinical manifestations and the common laboratory characteristics resembled those of the first type, but the plasma content of AHF-related protein was normal, as in haemophilia $\mathrm{A}$. The pedigrees suggested $\mathrm{X}$-chromosomal inheritance, with the exception that a few of the presumably heterozygous females had bleeding symptoms of the same degree as the presumably hemizygous males. However, the most severely affected girl belonged to a family with coexisting haemophilia A (Holmberg and Nilsson, 1972). She might therefore not only have had von Willebrand's disease but also have been a carrier of haemophilia $\mathrm{A}$.

In this second type of the disease the X-chromosomally induced part of the complex may be malformed, as it may be in haemophilia A, but then in such a way as to interfere with the ability of the complex to keep the bleeding time normal as well as to suppress the procoagulant activity.

This work was supported by grants from the Swedish Medical Research Council (B72-19X-87-08B).

\section{References}

Bennett, E., and Dormandy, K. (1966). Lancet, 2, 731.

Bennett, E., and Huehns, E. R. (1970). Lancet, 2, 956.

Bouma, B. N., van Mourik, J. A., Mochtar, I. A., and Sixma, J. J. (1971). International Society on Thrombosis and Haemostasis. II Congress, Oslo, July, p. 6. Abstract.

Cornu, P., Larrieu, M. J., Caen, J., and Bernard, J. (1961). Nouvelle Revue Française d'Hématologie, 1, 231.

Creveld, S. van, and Mochtar, I. A. (1960). Annales Pediatrici, 194, 37. Cronberg, S., Nilsson, I. M., and Silwer, J. (1966). Acta Medica Scandinavica, $180,43$.

Holmberg, L., and Nilsson, I. M. (1972). Acta Paediatrica Scandinavica.

In press.
Hoyer, L. W., and Breckenridge, R. T. (1968). Fournal of Laboratory and Clinical Medicine, 72, 883.

Larrieu, M. K., Caen, J. P., Meyer, D. O., Vainer, H., Sultan, Y., and Bernard, J. (1968). American fournal of Medicine, 45, 354.

Laurell, C.-B. (1966). Analytical Biochemistry, 15, 45.

Meyer, D., and Larrieu, M. J. (1971). European fournal of Clinical Investigation, 1,425 .

Nilsson, I. M., and Blombäck, M. (1962). Thrombosis et Diathesis Haemorrhagica, 9, Suppl. No. 2, p. 103.

Nilsson, I. M., Blombäck, M., and von Francken, I. (1957a). Acta Medica Scandinavica, 159, 35.

Nilsson, I. M., Blombäck, M., Jorpes, E., Blombäck, B., and Johansson, S.-A. (1957b). Acta Medica Scandinavica, 159, 179.

Nilsson, I. M., Blombäck, M., and Blombäck, B. (1959). Acta Medica Scandinavica, 164, 263.

Nilsson, I. M. Magnusson, S., and Borchgrevink, C. (1963). Thrombosis et Diathesis Haemorrhagica, 10, 223.

Nilsson, I. M., Blombäck, M., and Ahlberg, $\AA$. (1970). Bibliotheca Haematologica, 34, 111.

Ratnoff, O. D., Kass, L., and Lang, P. D. (1969). fournal of Clinical Investigation, 48, 957

Salzman, E. W. (1963). Fournal of Laboratory and Clinical Medicine, 62, 724

Silwer, J., and Nilsson, I. M. (1964). Acta Medica Scandinavica, 175, 627. tites, D. P., Hershgold, E. J., Perlman, J. D., and Fudenberg, H. H. (1971). Science, 171, 196

van Mourik, J. A., and Mochtar, I. A. (1970). Biochimica et Biophysica Acta 221, 677.

Zimmerman, T. S., Ratnoff, O. D., and Powell, A. E. (1971). fournal of Clinical Investigation, 50, 244.

\title{
Observations on Blood Glucose and Insulin Determinations
}

\author{
T. LIND, \\ H. A. VAN C. DE GROOT, \\ GAIL BROWN, \\ G. A. CHEYNE
}

British Medical fournal, 1972, 3, 320-323

\section{Summary}

The relation of capillary to venous blood glucose concentration, whole blood to plasma values, and, where possible, the effect of pregnancy on the variables have been studied. We have not been able to show constant \footnotetext{
M.R.C. Reproduction and Growth Unit, Princess Mary Maternity
Hospital, Newcastle upon Tyne

T. LIND, M.B., M.R.C.O.G., Member of Scientific Staff

GAIL BROWN, Technician

G. A. CHEYNE, F.I.M.L.T., Senior Technical Officer

Department of Obstetrics and Gynaecology, University of Newcastle upon Tyne

H. A. VAN C. DE GROOT, M.B., M.R.C.O.G., Senior Lecturer

(Present address: University of Cape Town, Department of Obstetrics and Gynaecology, Cape Town, South Africa)
}

relations between capillary and venous blood glucose concentrations as have been implied by a W.H.O. expert committee on diabetes mellitus and the British Diabetic Association.

The choice of anticoagulant was shown to have a negligible effect on the results of a single antibodycharcoal separation insulin assay method.

\section{Introduction}

In an earlier study of changes occurring in oral glucose tolerance tests during pregnancy we used capillary blood samples for glucose determinations (Lind et al., 1968). The use of capillary whole blood for this purpose is traditional and technically convenient, but the glucose concentration in extracellular fluid as represented by plasma or serum, is probably more meaningful from the point of view of physiology. In later studies plasma for insulin determinations was needed in amounts greater 
than could be obtained from the finger or ear lobe, and venous samples were taken. It was logical, therefore, to measure both insulin and glucose in the same samples of venous plasma.

This simple change in procedure posed two questions of comparability with previous data: firstly, the relation of capillary glucose concentration to venous blood concentration, and, secondly, the relation of whole blood concentration to plasma concentration. A subsidiary question was whether insulin determinations might be influenced by the anticoagulant used.

It has been known for many years that the concentration of glucose in capillary blood is generally higher than that in venous blood by a variable amount (Foster, 1923), but some official statements may give the impression that it is small and relatively constant. The W.H.O. Expert Committee on Diabetes Mellitus (1965) defined "normal" blood glucose concentrations two hours after a $50 \mathrm{~g}$ oral glucose load as being less than $120 \mathrm{mg} /$ $100 \mathrm{ml}$ in capillary blood and less than $110 \mathrm{mg} / 100 \mathrm{ml}$ in venous blood. A $10 \mathrm{mg}$ difference was also assumed with the higher two-hour "levels" in diabetes. On the other hand, Fitzgerald and Keen (1964), reporting for the British Diabetic Association, made recommendations suggesting that the difference becomes greater as the concentration increases $-10 \mathrm{mg} / 100 \mathrm{ml}$ two hours after a glucose load, $20 \mathrm{mg} / 100 \mathrm{ml}$ at the peak glucose concentration, but only $5 \mathrm{mg} / 100 \mathrm{ml}$ in fasting asymptomatic diabetics.

As regards insulin, Henderson (1970) reported that assay by a double antibody technique was best performed on serum because plasma prepared with heparin appeared to give artificially high results. Subsequent correspondence (Orosz et al., 1971 ; and Grant, 1972) suggested that anticoagulants influenced the separation stage through an effect on the second antibody.

This paper presents new evidence on the relation of capillary to venous blood glucose concentrations, whole blood to plasma values, and, where possible, the effect of pregnancy on these variables. The effect of different anticoagulants on a single antibody-charcoal separation insulin assay method is also discussed.

\section{Subjects and Methods}

All subjects whether pregnant or non-pregnant were chosen on the grounds of good general health, absence of family history of diabetes mellitus, and normal past obstetric history where applicable. There were different numbers of people in each group under investigation and these are specified in the appropriate sections.

Blood Samples.-Capillary blood was obtained by pricking the pulp of the second finger and the blood aspirated direct into a $0 \cdot 2-\mathrm{ml}$ pipette. This was immediately mixed into $1.8 \mathrm{ml}$ of a solution containing $160 \mathrm{mg}$ uranyl acetate and $900 \mathrm{mg}$ sodium chloride per $100 \mathrm{ml}$ water to precipitate proteins. Venous blood was usually taken from an antecubital vein and transferred to plain glass bottles when serum was required and lithium-heparin tubes for whole blood or plasma samples. Proteins were similarly precipitated as soon as possible afterwards and always within 15 minutes of collection. When paired samples of capillary and venous blood were required, one person obtained the venous sample and placed it in a lithium-heparin tube from which a second observer took up $0.2 \mathrm{ml}$ of whole blood and immediately precipitated the proteins. A third person meanwhile obtained capillary blood by finger-prick from the same arm. The samples were thus collected within 30 seconds of each other.

Glucose Determinations. - These were made in duplicate usually within four hours of the blood being collected. The duplicates were estimated independently by different technicians using the glucose oxidase-peroxidase method (Middleton and Griffiths, 1957). The accuracy of the method was estimated by determinations on 20 consecutive week-days of glucose standards, $180 \mathrm{mg} / 100 \mathrm{ml}, 90 \mathrm{mg} / 100 \mathrm{ml}$, and $45 \mathrm{mg} /$
$100 \mathrm{ml}$ preserved in saturated benzoic acid. The coefficient of variation was $2.9 \%$.

Insulin Assay.-The assay used was that developed by Dr. W. M. Hunter, of the M.R.C. Clinical Endocrinology Unit, Edinburgh (Hunter, 1969; Hunter and Ganguli, 1971). Each sample was assayed after dilution with the use of barbitone buffer containing horse serum to bring the insulin concentration within the standard range of 0.2-1.6 $\mu \mathrm{U} / \mathrm{ml}$. Doubling dilutions were used, fasting samples starting at the lowest range of $1: 4$ to $1: 32$, while higher concentrations might need to be diluted $1: 128$ to $1: 512$. The samples were then incubated at $4^{\circ} \mathrm{C}$ for four days with anti-insulin serum (Wellcome Reagents Ltd.). After adding ${ }^{125} \mathrm{I}$-insulin (Radiochemical Centre, Amersham) a further four days' incubation at $4^{\circ} \mathrm{C}$ was allowed before separation of free insulin from bound insulin by charcoal adsorption, the charcoal being suspended in a phosphate buffer containing human plasma proteins. A single sample of heparinized plasma assayed on nine separate occasions widely separated in time had a mean value of $22.9 \mu \mathrm{U} / \mathrm{ml}$ with an S.D. of 1.66 giving a coefficient of variation of $7.5 \%$. The insulin standards were always prepared from M.R.C. insulin reference standard 66/304.

\section{Results}

\section{CAPILLARY TO VENOUS GLUCOSE CONCENTRATIONS}

Twenty-eight healthy, non-pregnant volunteers had venous and capillary blood samples taken after fasting overnight and again 45 minutes after drinking $50 \mathrm{~g}$ of glucose (Lucozade). Thirty-six pregnant women provided fasting samples, and in a further 70 pregnant women samples were taken 45 minutes after a glucose load. Of the pregnant women 63 were at 36 or more completed weeks of gestation, 30 were between 30 and 36 weeks, and only 13 were below 30 weeks.

The mean capillary-venous difference in glucose concentration in the fasting state was small in both pregnant and non-pregnant groups, about $2 \mathrm{mg} / 100 \mathrm{ml}$, but the variation was greater in the non-pregnant subjects. After glucose the difference increased in both groups, both the absolute differences and the amount of variation being greater in non-pregnant women. The data are given in Table I.

The ranges of capillary-venous differences found at various capillary blood glucose concentrations are given in Table II. There does not appear to be a trend of increasing capillaryvenous difference as the blood glucose concentration rises.

TABLE I-Capillary-Venous Difference in Blood Glucose Concentration (mg/100 ml) for Pregnant and Non-pregnant Subjects

\begin{tabular}{cc|c|c|c|c}
\hline & & \multicolumn{2}{|c|}{ Fasting } & \multicolumn{2}{c}{ After Glucose } \\
\cline { 3 - 6 } & & Pregnant & $\begin{array}{c}\text { Non- } \\
\text { pregnant }\end{array}$ & Pregnant & $\begin{array}{c}\text { Non- } \\
\text { pregnant }\end{array}$ \\
\hline No. of subjects & $\ldots$ & 36 & 28 & 70 & 28 \\
\hline Mean difference & $\ldots$ & 2.6 & 1.9 & 9.5 & $24 \cdot 8$ \\
S.D. $\quad . \quad \cdots$ & $\cdots$ & 2.6 & 6.8 & 7.7 & 12.6 \\
\hline
\end{tabular}

TABLE II-Ranges of Capillary-Venous Difference by Capillary Blood Glucose Concentrations

\begin{tabular}{|c|c|c|c|}
\hline \multicolumn{2}{|c|}{$\begin{array}{c}\text { Capillary } \\
\text { Blood Glucose } \\
(\mathrm{mg} / 100 \mathrm{ml})\end{array}$} & Pregnant & Non-pregnant \\
\hline $\begin{array}{l}\leqslant 79 \\
80-\quad \cdots \\
100-\quad \cdots \\
120- \\
140 \text { and over }\end{array}$ & $\begin{array}{l}. \\
\because \\
\cdots\end{array}$ & $\begin{array}{l}-3 \text { to }+7(34) \\
-\quad 3 \text { to }+17(21) \\
+\quad 7 \text { to }+26(22) \\
+15 \text { to }+20(11) \\
+15 \text { to }+22(18)\end{array}$ & $\begin{array}{l}-11 \text { to }+7(17) \\
-5 \text { to }+31(18) \\
+16 \text { to }+43(8) \\
+11 \text { to }+41(10) \\
+10 \text { to }+45 \text { (3) }\end{array}$ \\
\hline
\end{tabular}

Figures in parentheses are numbers of subjects. 


\section{WHOLE BLOOD TO PLASMA GLUCOSE CONCENTRATIONS}

Glucose distributes itself in the water phase of blood, and differences of concentration depend largely on the water contents of each source. The likely range of variation in the water content of plasma and red cells has a relatively small influence on glucose concentration in whole blood compared with the proportion of red cells in whole blood. Differences of water content of these components of the blood are unlikely to change the ratio by more than 0.01 , while a change of $10 \%$ in packed cell volume (P.C.V.) will change the ratio by 0.04 (see Chart). Within the usual range of values of packed cell volume plasma glucose would be about $13 \%$ higher than the equivalent whole blood value.

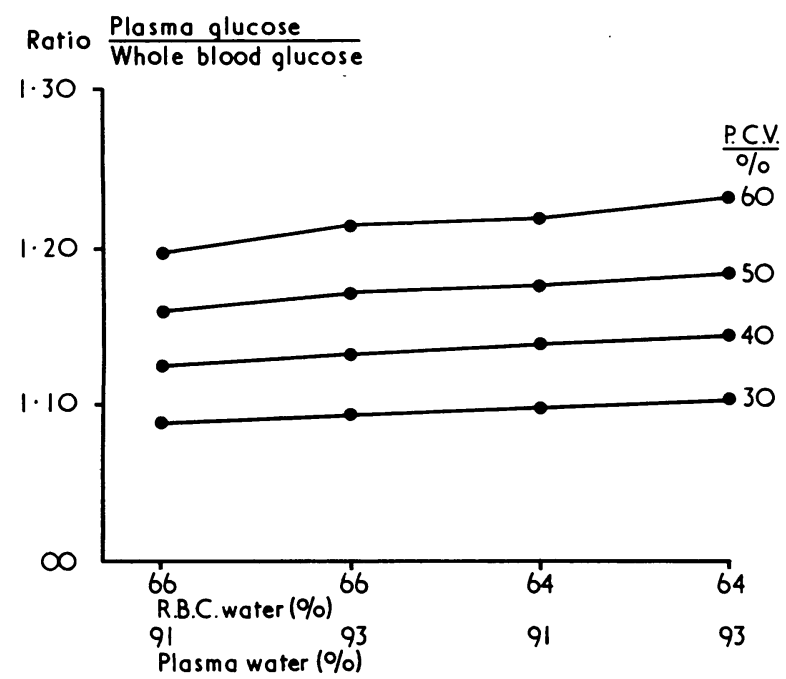
Effect of P.C.V. and various physiological combinations of red
blood cell (R.B.C.) water and plasma water content on the ratio of plasma water to whole blood water content.

Independent determinations of glucose concentrations were made on venous whole blood and plasma obtained from healthy pregnant volunteers having oral glucose tolerance tests in the course of a physiological study. Of 27 women tested in late pregnancy 25 had also had a glucose tolerance test before 20 weeks' gestation and 14 had a third test 10-12 weeks after delivery. In each of these 66 glucose tolerance tests samples of venous blood were obtained at $0,15,30,45,60,75,90$, and 120 minutes. The ratio of plasma glucose concentration to that estimated in whole blood was $1 \cdot 11$, with a standard error of 0.01 . In some subjects, however, the ratio varied from 0.96 to 1.22 so that while an average factor of 1.11 may be used for the conversion of whole blood to plasma values in groups of subjects it can be misleading in individuals.

\section{EFFECT OF ANTICOAGULANT ON INSULIN ASSAY}

Venous blood samples of about $20 \mathrm{ml}$ were collected from 30 pregnant and non-pregnant subjects in the fasting and fed states to obtain a wide range of insulin concentrations. Standard disposable tubes (Teklab) containing various anticoagulants were used. As soon as the blood was obtained, $2 \mathrm{ml}$ was placed in a lithium-heparin tube, $2.5 \mathrm{ml}$ into an edetic acid tube, and $2.5 \mathrm{ml}$ into an oxalate tube for plasma samples; the remaining blood was put into a dry glass bottle and allowed to clot at room temperature. Serum in the amounts specified above for blood was then put into similar anticoagulant tubes giving serum lithium-heparin, serum-edetic acid, and serum oxalate samples, and some plain serum was retained for assay. For various reasons eight samples were not tested with oxalate and six were not tested with edetic acid.

The absolute differences of insulin concentration between samples treated with different anticoagulants varied according to the concentration of insulin present-for example, the mean value of plasma lithium-heparin minus plasma edetic acid was $0.3 \mu \mathrm{U} / \mathrm{ml}$ for insulin values below $10 \mu \mathrm{U} / \mathrm{ml}, 2 \cdot 2 \mu \mathrm{U} / \mathrm{ml}$ for concentrations between 10 and $50 \mu \mathrm{U} / \mathrm{ml}$, and $7.0 \mu \mathrm{U} / \mathrm{ml}$ for concentrations above $50 \mu \mathrm{U} / \mathrm{ml}$. Ratios of one estimation to another have therefore been used, as in this way the dilution factor is cancelled out and the results give a percentage difference applicable at any level of insulin. The ratios are reasonably consistent and not systematically affected by insulin concentrations (Table III). Oxalate gave small but significantly lower insulin values than those obtained with plasma lithium-heparin, plasma edetic acid, serum, or serum lithium-heparin; this anticoagulant is unlikely to be used for blood glucose or insulin estimations but the point is worth noting.

\section{Conclusions}

We have not been able to show constant relations between capillary and venous blood glucose concentrations as implied by the recommendations of the W.H.O. Expert Committee on Diabetes Mellitus (1965) and the British Diabetic Association (Fitzgerald and Keen, 1964). At fasting levels the capillaryvenous differences are too trivial to be worth correcting, especially during pregnancy. For higher levels the range is so variable that the use of a standard correction factor cannot be justified even for groups of subjects.

When specific enzyme methods for determining glucose in blood came into use the above authorities adjusted their diagnostic criteria to the lower "true blood glucose" values. We now need an equally authoritative lead towards standardization of other aspects of technique. Capillary blood samples, because they are easy to obtain and can be taken by nursing and technical staff, may well have to remain the basis on which the day-to-day management of insulin-taking diabetic patients will rest. For research purposes, however, or when investigating a

TABLE III-Mean Ratios of Various Anticoagulant Samples According to Insulin Concentration

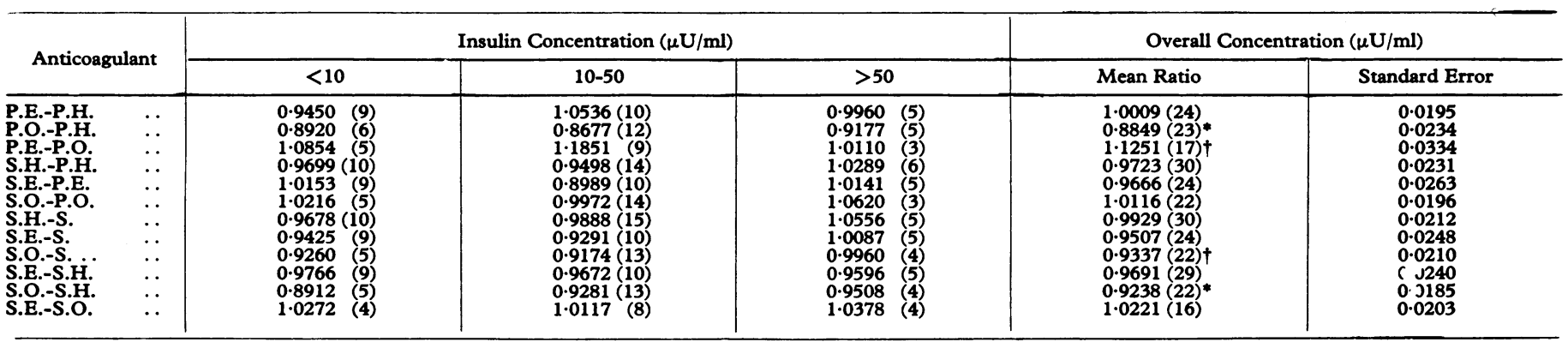

- Significance of difference from $1 \cdot 0=0.001$

tSignificance of difference from $1 \cdot 0=0 \cdot 01$.

Figures in parentheses are numbers of observations.

P. = Plasma. S. = Serum. $\mathbf{H}=$ Lithium-heparin. $\mathbf{O}$. = Oxalate. $\mathrm{E}$. = Edetic acid. 
possible case of diabetes for the first time plasma glucose values ought to be reported. If anticoagulants interfere with the precipitating second antibody of double antibody insulin assay systems then separation of insulin ought to be achieved by other methods-for example, by adsorption to charcoal. They are equally efficient and simple to use.

Glucose and insulin responses are being studied under widely varying circumstances-relation between mother and fetus, hypoglycaemic disturbances in the neonate, and the effects of new oral hypoglycaemic agents. Precise comparisons of data in these and other fields cannot be made unless glucose and insulin concentrations are determined on the same basis. An agreement on basic methodology will help to save a great deal of confusion in the future.

Requests for reprints should be addressed to Dr. T. Lind, M.R.C.
Reproduction and Growth Unit, Princess Mary Maternity Hospital, Great North Road, Newcastle upon Tyne NE2 3BD.

\section{References}

Fitzgerald, M. G., and Keen, H. (1964). British Medical fournal, 1, 1568 Foster, G. L. (1923). Fournal of Biological Chemistry, 55, 291.

Grant, D. B. (1972). Lancet, 1, 207.

Henderson, J. R. (1970). Lancet, 2, 545.

Hunter, W. M. (1969). In Protein and Polypeptide Hormones, ed. M. Margoulies, I.C.S. No. 161. Amsterdam, Excerpta Medica.

Hunter, W. M., and Ganguli, P. C. (1971). In Radioimmunoassay Methods, ed. K. E. Kirkham and W. M. Hunter, p. 243. Edinburgh, Livingstone.

Lind, T., Cheyne, G. A., Billewicz, W. Z., and Fairweather, D. V. I. (1968) fournal of Obstetrics and Gynaecology of the British Commonwealth, 75, 540.

Middleton, J. E., and Griffiths, W. J. (1957). British Medical fournal, 2, 1525.

Orosz, L., Michael, R., and Ziegler, M. (1971). Lancet, 2, 1149.

Orosz, L., Michael, R., and Ziegler, M. (1971). Lancet, 2, 1149.
W.H.O. Expert Committee on Diabetes Mellitus (1965). World Health Organization. Technical Report Series, No. 310.

\title{
Infective Factors in Exacerbations of Bronchitis and Asthma
}

\author{
H. P. LAMBERT, H. STERN
}

British Medical fournal, 1972, 3, 323-327

\section{Summary}

Infections of the respiratory tract were studied in a group of families each containing a patient with chronic bronchitis or with asthma. A wide variety of infective agents may be associated with exacerbations in susceptible subjects, but the types of organism to which patients are most at risk differ according to the family structure. Exacerbations in the susceptible subject are more likely to be related to viral infections when the family contains children than when it does not.

Two patients with asthma experienced frequent respiratory infections, many of which provoked attacks of asthma.

\section{Introduction}

Attempts to assess the role of infective agents in promoting exacerbations of chronic bronchitis and other chronic respiratory diseases have given rise to widely discrepant results. Many agents have been found in association with exacerbations, but their relative importance has varied greatly in different studies. In particular, viruses have been identified with very variable frequency in several careful surveys (Somerville, 1963; Carilli et al., 1964; Eadie et al., 1966; Ross et al., 1966; Stenhouse, 1967; McNamara et al., 1969; Fisher et al., 1969). The paucity of viruses in some surveys is hard to reconcile with the common observation made in general practice that patients often have exacerbations of bronchitis when other members of the family are suffering mild, and presumably mainly viral, infection of the respiratory tract. One reason for this discrepancy may be that few studies have been made in the patient's home, and as soon

\section{St. George's Hospital, London S.W.17}

H. P. LAMBERT, M.D., F.R.C.P., Consultant Physician

St. George's Hospital Medical School, London S.W.1

H. STERN, M.B., F.R.C.PATH, Professor of Virology as possible after the onset of symptoms; viral pathogens provoking exacerbations of chronic respiratory disease might well be more difficult to identify by the time the patient has reached hospital. The family structure too, particularly the presence and age of children, might affect the chances of virus-induced exacerbations in a susceptible subject.

In the present study an attempt was made to identify infective agents implicated in provoking exacerbations of bronchitis or of asthma within the patients' households, and to study the distribution and spread of such agents in the families of these susceptible subjects. In this way it was hoped to make some estimate of the types of infective risk which "chesty" people may experience in their own homes.

\section{Methods}

Eight families, each containing at least one member with chronic bronchitis or asthma, were studied in considerable detail over an average period of two years. Each family wis visited every two weeks by a nurse specially trained in the taking of specimens, and additional visits were made if the susceptible patient developed a respiratory illness. At each visit a record card was completed for every member of the family, giving information about the following symptoms; cold, sore throat, earache, cough, sputum, wheezing, general aching, fever, diarrhoea, and vomiting. In the case of persistent symptoms, such as cough and sputum, a simple code was recorded denoting "better," "worse," or "the same." An exacerbation was defined as an increase in any two of the three symptoms of cough, sputum, and wheezing. Visits to the family doctor, or by the family doctor to the house, were also noted, together with the doctor's diagnosis.

At every visit the following specimens were taken from each member of the family: a throat swab into Stuart's transport medium for Streptococcus pyogenes, throat and nasal swabs placed together in viral transport medium, and a further throat swab which was inoculated directly into diphasic mycoplasma medium (Grayston et al., 1965). Sputum from the susceptible subjects was similarly examined for viral, mycoplasmal, and bacterial pathogens. A stool specimen for enterovirus isolation was often obtained by using containers left on the previous visit. 